\title{
EFFECT OF IMPORT TARIFF ON A BILATERAL TRADE
}

\author{
Deergha Raj Adhikari, University of Louisiana at Lafayette, U.S.A. \\ S. P. Uma Rao, University of Louisiana at Lafayette, U.S.A. \\ Denis Boudreaux, University of Louisiana at Lafayette, U.S.A.
}

dx.doi.org/10.18374/JIFE-19-3.6

\begin{abstract}
One of the objectives of imposing a tariff on the import of steel and aluminum, as cited by President Donald Trump, was to substantially lower its trade deficit. Germany is one of the countries that have been affected by the tariff. This study investigates the impact of the tariff on U.S. - Germany trade, to see how likely the policy is to curb the U.S. trade deficit with Germany. One of the ways an import tariff affects a nation's economy is by raising the price of the importable in domestic market and lowering its import leading to an improvement in the country's trade balance in the long run. In short run, however, the effect is just the opposite. Since it takes time for the domestic consumers of foreign products to adjust their demand to the price increase, the demand for foreign products does not fall immediately following the tariff laid price increase, raising the nation's import bills for the time being leading to the deterioration of its trade balance. Thus the deterioration of trade balance in the short run and its improvement in the long run produce a J-curve phenomenon. In exporting countries the tariff has a different effect, however. An import tariff by the importing country lowers the exporting country's export causing a fall in the supply of the foreign currency the export is quoted in, which raises the price of the foreign currency. If the foreign currency in which the export is quoted happens to be same as that of the importing country, then an appreciation of the foreign currency produces an inverse J-curve effect in the importing country. This appreciation of the importing country's currency makes its imports less expensive and its export more expensive, which increases its imports and lowers its exports in the short term, thereby, producing an inverse J-curve effect. This study intends to test the J-curve effect on trade between the U.S. and Germany using the vector error correction model (VECM). The estimation of the long-run equation shows that the coefficient associated with the exchange rate variable, is negative but insignificant, which implies that any appreciation of the U.S. dollar resulting from the fall in U.S. import from Germany will have no effect on U.S. trade balance with Germany in the long run. The estimation of the short-run equation, on the other hand, shows that the coefficients associated with the variables is positive but insignificant while that associated with is both positive and significant at $5 \%$ significance level, which implies that any appreciation of the U.S. dollar resulting from the imposition of the U.S. import tariff will deteriorate U.S. trade balance with Germany in the short run. This finding indicates that there is an absence of the J-curve effect in the U.S.-Germany trade. Also, the coefficient associate with the error-correction term, ECT, is negative and significant, implying that any short term fluctuation in U.S. trade balance with Germany will be adjusted at the speed of $99 \%$ toward its long-run value.
\end{abstract}

Keywords: J-curve effect, export-to-import ratio, exchange rate, unit root, cointegration 